\title{
Hubungan Tingkat Pendidikan dan Pengetahuan Penjual Es Campur Tentang Zat Pewarna Berbahaya dengan Kandungan Rhodamin B dalam Buah Kolang Kaling di Kota Padang
}

\author{
Rizki Hidayah ${ }^{1}$, Asterina $^{2}$, Afriwardi $^{3}$
}

\begin{abstract}
Abstrak
Penggunaan Bahan Tambahan Pangan (BTP) dewasa ini sangat beragam dan sering berakibat buruk terhadap kesehatan. Badan Pengawas Obat dan Makanan (BPOM) Padang pada Juni 2016 di empat kecamatan di Kota Padang mendapatkan lima dari 75 sampel makanan yang diperiksa mengandung rhodamin $\mathrm{B}$. Tujuan penelitian ini adalah menentukan hubungan tingkat pendidikan dan pengetahuan penjual es campur tentang zat pewarna berbahaya terhadap kandungan rhodamin B dalam buah kolang kaling di Kota Padang. Jenis penelitian ini adalah analitik dengan pendekatan cross sectional. Teknik pengambilan sampel dalam penelitian ini adalah cluster random sampling dan sampel penelitian adalah 11 pasar tradisional yang ada di Kota Padang dengan jumlah sampel yang didapatkan sebanyak 31 sampel. Penelitian dilaksanakan pada Agustus 2016 sampai April 2017. Analisis data menggunakan uji Fisher. Hasil penelitian menunjukan tidak terdapat hubungan yang bermakna antara tingkat pendidikan $(p=0,935)$ dan pengetahuan tentang zat pewarna berbahaya $(p=0,283)$ dengan kandungan rhodamin $B$ pada buah kolang kaling. Simpulan dari penelitian ini, baik tingkat pendidikan maupun pengetahuan penjual tentang zat pewarna berbahaya tidak terdapat hubungan yang bermakna. Hal ini menunjukkan bahwa tingkat pendidikan penjual yang relatif rendah dan pengetahuan yang cukup tidak menjadi faktor yang menentukan makanan yang dijual tidak sehat dan tidak layak konsumsi.
\end{abstract}

Kata kunci: rhodamin B, tingkat pendidikan, pengetahuan

\begin{abstract}
The use of food additives today is extremely diverse and often have adverse effects for health. In four districts of Padang, BPOM found five out of 75 food samples that contained rhodamine $B$ on June 2016. The objective of this study was to determine the relationship between the education level and knowledge about hazardous dye substances of es campur seller on the content of rhodamine $B$ in sugar palm fruits in Padang. This study was an analytic with cross-sectional approach. The samples were taken by cluster random sampling with a total of 31 samples from 11 traditional markets in Padang throughout August 2016 until April 2017. Data were analyzed using Fisher's exact test. Bivariate test results showed that there are no significant correlation between education level $(p=0.935)$ and the knowledge of hazardous dye $(p=0.283)$ towards the content of rhodamine $B$ in sugar palm fruits. In conclusion, there is no significant correlation between education level and knowledge about hazardous dye substances of the seller towards the content of rhodamine $B$ in sugar palm fruits. This shows that low educational level and intermediate knowledge of the seller determined to be one of the factors of unhealthy and unfit food for consumption.
\end{abstract}

Keywords: rhodamine $B$, education level, knowledge

Affiliasi penulis: 1. Prodi Profesi Dokter FK Unand (Fakultas Kedokteran Universitas Andalas Padang); 2. Bagian Kimia FK Unand; 3. Bagian Fisiologi FK Unand
Korespondensi: Rizki Hidayah, Email: rizkihidayahs@gmail.com Telp: 082113523393 


\section{PENDAHULUAN}

Makanan jajanan (street food) telah menjadi bagian yang tidak terpisahkan dari kehidupan masyarakat, baik di perkotaan maupun di pedesaan. Keunggulan makanan jajanan adalah murah dan mudah didapat, serta cita rasanya enak dan cocok dengan selera kebanyakan masyarakat. Meskipun memiliki beberapa keunggulan, tetapi makanan jajanan juga berisiko terhadap kesehatan, hal ini disebabkan oleh proses pembuatan yang sering tidak higienis atau sering kali ditambahkan bahan tambahan pangan yang tidak diizinkan. ${ }^{1}$

Biji buah aren (Arenga pinnata) muda merupakan biji buah yang sangat digemari sebagai bahan makanan rendah kalori. Biji buah aren lebih dikenal dengan nama kolang kaling. Kolang kaling berbentuk lonjong dan memiliki warna yang transparan. Berdasarkan hasil penelitian dari Balai Penelitian dan Pengembangan Industri Manado tahun 1986, kadar kimiawi pada biji buah aren (kolang kaling) yaitu selulosa $19,08 \%$, pati $50,89 \%$, protein $12,23 \%$, dan abu $17,78 \%{ }^{2}$

Kolang kaling merupakan biji buah aren yang telah diolah dan dapat dimanfaatkan untuk bahan aneka makanan dan minuman yang banyak beredar di masyarakat. Tekstur buah yang kenyal, bentuknya yang lonjong dan memiliki kandungan air yang tinggi membuat kolang kaling digemari oleh masyarakat. Kolang kaling banyak digunakan sebagai bahan tambahan di dalam es buah (es campur). Dalam pengolahannya, kolang kaling biasanya ditambahkan bahan tambahan pangan berupa zat pewarna agar terlihat lebih menarik. ${ }^{3}$

Zat aditif adalah semua zat atau campuran zat selain bahan dasar yang terdapat dalam makanan sebagai akibat dari produksi, pemrosesan, penyimpanan, dan pengemasan. Zat aditif berperan penting dalam rantai pemrosesan makanan agar tetap aman setibanya di meja makan konsumen. Meskipun demikian, tidak berarti setiap makanan yang diproses mengandung zat aditif. ${ }^{4}$

Bahan tambahan pangan adalah senyawa yang sengaja ditambahkan ke dalam makanan dengan jumlah dan ukuran tertentu dan terlibat dalam proses pengolahan, pengemasan, dan atau penyimpanan. Bahan ini berfungsi untuk memperbaiki warna, bentuk, cita rasa, dan tekstur, serta memperpanjang masa simpan, dan bukan merupakan bahan utama. ${ }^{1}$

Penggunaan bahan tambahan pangan dewasa ini sangat beragam. Berkembangnya bahan tambahan pangan mendorong pula perkembangan makanan hasil olahan pabrik, yakni bertambah ragam jenisnya serta ragam cita rasa maupun kenampakannya. Sayangnya, penggunaan bahan tambahan pangan sering kali berakibat buruk terhadap kesehatan. Beberapa faktor penyebabnya adalah kurangnya sosialisasi tentang dosis, manfaat, dan bahaya akibat penggunaan bahan tambahan pangan secara salah. Faktor lainnya yaitu penggunaan bahan yang sebenarnya bukan untuk pangan, karena alasan ekonomi, seperti penggunaan pewarna tekstil untuk bahan makanan karena harganya yang lebih murah daripada pewarna makanan. ${ }^{1}$

Pewarna pangan adalah zat yang digunakan untuk memberikan atau meningkatkan warna suatu produk pangan, sehingga menciptakan image tertentu dan membuat produk lebih menarik. Pewarna pangan di klasifikasikan berdasarkan asalnya, yaitu pewarna alami dan pewarna sintetik. Pewarna pangan yang berasal dari bahan alam disebut pewarna alami. Pewarna sintetik adalah pewarna yang dibuat melalui sintesis secara kimia. ${ }^{5}$

Penggunaan bahan kimia sebagai pewarna diatur oleh Peraturan Menteri sebab tidak semua bahan kimia dapat digunakan sebagai pewarna dan dosis penggunaannya pun dibatasi agar tidak berbahaya bagi kesehatan. Zat pewarna yang diizinkan penggunaannya adalah carmoisine, amaranth, erythrosin, tartrazine, fast green FCF, sunset yellow. Sedangkan zat pewarna yang dilarang penggunaannya salah satunya adalah rhodamin B, guinea green $B$ dan methanil yellow. Walau telah diatur penggunaan bahan pewarna dalam makanan tetapi masih banyak pedagang yang menggunakan zat berbahaya pada pewarna makanan. Rhodamin B merupakan salah satu zat yang dilarang digunakan dalam kegiatan atau proses produksi pangan, tetapi penggunaannya masih terus digunakan oleh produsen dalam mewarnai produk makanan. ${ }^{6}$

Rhodamin B berbahaya bagi kesehatan manusia karena sifat kimia dan kandungan logam beratnya. Rhodamin B juga mengandung klorin $(\mathrm{Cl})$. 
Senyawa klorin merupakan senyawa halogen yang berbahaya dan reaktif. Jika tertelan, maka senyawa ini akan berusaha mencapai kestabilan dalam tubuh dengan cara mengikat senyawa lain dalam tubuh, hal inilah yang bersifat racun bagi tubuh. Penggunaan rhodamin B dilarang karena termasuk bahan karsinogen yang kuat. Konsumsi rhodamin B dalam jangka panjang dapat terakumulasi di dalam tubuh dan dapat menyebabkan gejala pembesaran hati dan ginjal, gangguan fungsi hati, kerusakan hati, gangguan fisiologis tubuh, atau bahkan bisa menyebabkan timbulnya kanker hati. $^{7}$

Pada umumnya penjual makanan jajanan tidak menyadari bahaya penggunaan bahan tambahan yang dilarang. Hal ini terutama disebabkan ketidaktahuan para penjual baik mengenai sifat-sifat maupun cara penggunaan bahan tambahan yang tidak sesuai aturan. Penjual makanan jajanan biasanya adalah masyarakat yang tingkat pendidikannya rendah, sehingga kurang memperhatikan tingkat keamanan pangan yang dibuat dan dijualnya. ${ }^{8}$

Kasus penyalahgunaan zat pewarna sebagai bahan tambahan pangan masih banyak dijumpai di berbagai daerah di Indonesia, termasuk di Kota Padang. Salah satu penyebabnya adalah pengetahuan penjual yang rendah mengenai keamanan penggunaan bahan tambahan pada pangan. Pengetahuan pembuat dan penjual makanan jajanan memiliki pengaruh yang besar terhadap kualitas makanan. ${ }^{9}$

Es campur merupakan salah satu minuman yang disukai oleh masyarakat yang umumnya ditambahkan kolang kaling. Survey yang telah dilakukan oleh penulis di beberapa pasar di Kota Padang, peneliti mendapatkan kolang kaling yang ditambahkan ke dalam es campur telah diberi pewarna. Berdasarkan pemaparan diatas, penulis tertarik melakukan penelitian untuk mengetahui hubungan tingkat pendidikan dan pengetahuan penjual es campur tentang zat pewarna berbahaya dengan kandungan rhodamin $\mathrm{B}$ dalam buah kolang kaling di Kota Padang.

\section{METODE}

Penelitian ini dilakukan di 11 pasar tradisional yang ada di Kota Padang pada bulan Agustus 2016 sampai April 2017. Populasi penelitian ini adalah penjual es campur dengan kolang kaling berwarna merah sebagai isi dari es campur dengan jumlah sampel sebanyak 31 penjual. Pengambilan sampel menggunakan teknik cluster random samplnig.

Penelitian ini menggunakan pendekatan crosssectional study. Pengumpulan data melalui data primer yang diperoleh dari pegujian di laboratorium kimia Fakultas Kedokteran Universitas Andalas dan wawancara langsung kepada penjual es campur. Data yang diperoleh kemudian diolah secara statistik. Analisis statistik yang digunakan yaitu uji Fisher.

\section{HASIL}

Berdasarkan hasil penelitian, diperoleh data jumlah responden berdasarkan faktor yang diteliti (tingkat pendidikan, pengetahuan, dan kandungan rhodamin B) pada Tabel 1.

Tabel 1. Jumlah subjek penelitian

\begin{tabular}{lcc}
\hline Karakteristik & Jumlah & Persentase \\
\hline Tingkat & & \\
$\begin{array}{l}\text { Pendidikan } \\
\text { Rendah }\end{array}$ & 29 & $93,5 \%$ \\
$\quad$ Tinggi & 2 & $6,5 \%$ \\
\hline Pengetahuan & & \\
$\quad$ Kurang & 9 & $29,0 \%$ \\
$\quad$ Sedang & 16 & $51,6 \%$ \\
$\quad$ Baik & 6 & $19,4 \%$ \\
\hline Kandungan & & \\
Rhodamin B & & \\
$\quad$ Negaif & 30 & $96,78 \%$ \\
Positif & 1 & $3,22 \%$ \\
\hline
\end{tabular}

Berdasarkan Tabel 1 menunjukkan bahwa responden penelitian sebagian besar memiliki tingkat pendidikan rendah (93,5\%). Dilihat dari segi pengetahuan, responden penelitian sebagian besar memiliki pengetahuan dengan kategori sedang $(51,6 \%)$. Sedangkan jika dilihat dari hasil uji kandungan rhodamin $\mathrm{B}$, sebagian besar responden didapatkan tidak menggunakan rhodamin B $(96,78 \%)$. 
Hubungan tingkat pendidikan penjual es campur dengan kandungan rhodamin $B$

Tabel 2. Hubungan tingkat pendidikan penjual es campur dengan kandungan rhodamin $\mathrm{B}$

\begin{tabular}{ccccccc}
\hline \multirow{2}{*}{$\begin{array}{c}\text { Tingkat } \\
\text { Pendidikan }\end{array}$} & \multicolumn{2}{c}{ Kandungan Rhodamin B } & \multirow{2}{*}{ Total } & $\mathbf{p}$ \\
\cline { 2 - 5 } & $\mathbf{n}$ & $\%$ & $\mathbf{n}$ & $\%$ & $\mathbf{n}$ & \\
\hline Rendah & 28 & 93,5 & 1 & 6,5 & 29 & \\
\hline Tinggi & 2 & 100 & 0 & 0 & 2 & 5 \\
Total & 30 & & 1 & & 31 &
\end{tabular}

Berdasarkan Tabel 2 didapatkan bahwa dari 29 responden dari kategori tingkat pendidikan rendah, terdapat ada 1 responden didapatkan positif mengandung rhodamin B. Sedangkan dari kategori tingkat pendidikan tinggi didapatkan tidak ada kolang kaling yang positif mengandung rhodamin $B$. Berdasarkan hasil uji Fisher, didapatkan nilai $p$ sebesar 0,935 $(p>0,05)$. Hal ini menunjukan bahwa tidak terdapat hubungan antara tingkat pendidikan penjual dengan kandungan rhodamin $\mathrm{B}$.

\section{Hubungan pengetahuan penjual es campur tentang zat pewarna berbahaya dengan kandungan rhodamin $\mathrm{B}$}

Tabel 3. Hubungan pengetahuan penjual es campur tentang zat pewarna berbahaya dengan kandungan rhodamin $\mathrm{B}$

\begin{tabular}{|c|c|c|c|c|c|c|}
\hline \multirow{3}{*}{$\begin{array}{l}\text { Pengetahu- } \\
\quad \text { an }\end{array}$} & \multicolumn{4}{|c|}{ Kandungan Rhodamin B } & \multirow[t]{2}{*}{ Total } & \multirow[t]{3}{*}{$\mathbf{p}$} \\
\hline & \multicolumn{2}{|c|}{ Negatif } & \multicolumn{2}{|c|}{ Positif } & & \\
\hline & $\mathrm{n}$ & $\%$ & $n$ & $\%$ & $\mathrm{n}$ & \\
\hline Kurang & 8 & 88,8 & 1 & 11,2 & 9 & \\
\hline Sedang & 16 & 100 & 0 & 0 & 16 & \\
\hline Baik & 6 & 100 & 0 & 0 & 6 & \\
\hline Total & 30 & & 1 & & 31 & \\
\hline
\end{tabular}

Berdasarkan Tabel 3 dapat dilihat bahwa dari 9 responden dengan pengetahuan kurang, hanya ada 1 responden yang didapatkan positif mengandung rhodamin B. Sedangkan dari responden yang memiliki pengetahuan sedang dan baik, tidak ada kolang kaling yang positif mengandung rhodamin B. Berdasarkan hasil uji Fisher, didapatkan nilai $p$ sebesar 0,283
( $p>0,05)$. Hal ini menunjukan bahwa tidak terdapat hubungan antara pengetahuan penjual dengan kandungan rhodamin $\mathrm{B}$.

\section{PEMBAHASAN}

Berdasarkan penelitian yang dilakukan di 11 pasar tradisional di Kota Padang, didapatkan jumlah pedagang yang menjual es campur dengan kolang kaling berwarna merah sebagai isi dari es campur jumlahnya bervariasi di tiap pasar, berkisar 2-5 penjual di tiap pasar. Dilihat dari tingkat pendidikan, sebagian besar penjual memiliki tingkat pendidikan rendah (93,5\%). Dari segi pengetahuan, sebagian besar penjual memiliki pengetahuan dengan kategori sedang $(51,6 \%)$. Sedangkan dari kandungan rhodamin B pada kolang kaling dalam es campur, sebagian besar hasilnya negatif mengandung rhodamin $B(96,8 \%)$.

Hasil uji statistik dengan menggunakan uji Fisher menunjukan bahwa tidak terdapat hubungan bermakna antara tingkat pendidikan dengan kandungan rhodamin $B$, dimana nilai $p=0,935$ $(p>0,05)$. Hasil penelitian ini sejalan dengan hasil penelitian yang dilakukan oleh Djarismawati et al pada tahun 2004. Dalam peneitian tersebut didapatkan bahwa tidak terdapat hubungan bermakna antara tingkat pendidikan dengan pemberian zat pewarna rhodamin B pada cabe merah giling. ${ }^{10}$

Menurut Notoadmodjo (2003), pendidikan merupakan salah satu faktor yang bisa mempengaruhi persepsi seseorang untuk menerima ide-ide baru. Semakin tinggi tingkat pendidikan seseorang, maka orang tersebut akan mudah untuk menerima informasi. $^{11}$

Pendidikan pada dasarnya adalah usaha sadar untuk mengembangkan kepribadian dan kemampuan peserta didik. Dengan pendidikan, peserta didik akan memiliki bermacam-macam kemampuan baik kognitif, afektif, maupun motorik. Kemampuan kognitif berkaitan dengan pengetahuan dan kemampuan berpikir. Kemampuan afektif berkaitan dengan sikap. Sedangkan kemampuan motorik berkaitan dengan tindakan atau praktik. Makin tinggi pendidikan seseorang makin tinggi kemampuan yang diperoleh. Sebaliknya, makin rendah pendidikan seseorang makin sedikit kemampuan yang diperoleh. Adanya 
kemampuan yang tinggi memungkinkan seseorang dapat mengembangkan pengetahuan, sikap dan praktik yang mereka lakukan. ${ }^{8}$

Tingkat pendidikan bukan satu-satunya faktor yang menentukan kemampuan seseorang untuk dapat mengembangkan pengetahuan dan sikap untuk melakukan suatu hal. Pengalaman memecahkan masalah yang pernah dialami di masa yang lalu juga menentukan sikap seseorang terhadap suatu hal. Seseorang yang memiliki tingkat pendidikan yang rendah, namun mendapatkan informasi yang baik dari berbagai media seperti televisi, radio, surat kabar, majalah dan lain-lain, juga dapat meningkatkan pengetahuan seseorang. ${ }^{11}$

Peneliti dapat menyimpulkan bahwa meskipun sebagian besar penjual es campur di Kota Padang memiliki tingkat pendidikan rendah, hanya sedikit sekali penjual yang menambahkan rhodamin B pada makanan yang dijualnya. Hal ini menunjukkan bahwa tingkat pendidikan penjual yang relatif rendah tidak menjadi faktor yang menentukan makanan yang dijualnya tidak sehat dan tidak layak konsumsi. Akan tetapi tetap harus diwaspadai karena pada makanan jajanan yang dijual masih ada yang mengandung zat pewarna berbahaya seperti rhodamin B walaupun jumlahnya sangat sedikit.

Hasil uji statistik dengan menggunakan uji Fisher menunjukan bahwa tidak terdapat hubungan bermakna antara pengetahuan dengan kandungan rhodamin $B$, dimana nilai $p=0,283(p>0,05)$. Hasil penelitian yang dilakukan oleh Kurniawaty dan Oksariani pada tahun 2010 sejalan dengan hasil penelitian ini. Dalam penelitian tersebut didapatkan bahwa tidak terdapat hubungan bermakna antara pengetahuan penjual terhadap perilaku penggunaan rhodamin B pada cabe merah giling. ${ }^{12}$

Pengetahuan bukanlah satu-satunya faktor yang mempengaruhi perilaku dan tindakan seseorang terhadap suatu hal. Usia dapat menjadi faktor yang mempengaruhi. Usia mempengaruhi daya tangkap dan pola pikir seseorang, semakin bertambah usia maka semakin berkembang pula daya tangkap dan pola pikir seseorang. Setelah melawati usia madya (40-60 tahun), daya tangkap dan pola pikir seseorang akan menurun. Penyebaran informasi yang cepat dan mudah diakses di masa kini juga dapat mengubah pola fikir dan tindakan seseorang terhadap suatu hal. Begitu juga dengan interaksi seseorang terhadap lingkungan sekitar. ${ }^{11}$

\section{SIMPULAN}

Tidak terdapat hubungan yang bermakna antara tingkat pendidikan penjual es campur dengan kandungan rhodamin B dalam buah kolang kaling yang dijual di Kota Padang.

Tidak terdapat hubungan yang bermakna antara pengetahuan penjual es campur tentang zat pewarna berbahaya dengan kandungan rhodamin $B$ dalam buah kolang kaling yang dijual di Kota Padang.

\section{DAFTAR PUSTAKA}

1. Saparinto C, Hidayati D. Bahan tambahan pangan. Yogyakarta: Penerbit Kanisius; 2006.

2. Sanjaya, Madyanti T. Pengaruh $\mathrm{NaClO}$ terhadap sifat kertas berbahan baku biji buah aren (Arenga pinnata) muda (kolang kaling). Prosiding semnas penelitian, pendidikan dan penerapan MIPA; Yogyakarta: FMIPA-UNY; 2005. hlm. 215-8.

3. Tusiyem, Suroso A, Retnowaty SF, Wirman SP. Uji fisis dan $\mathrm{pH}$ manisan air buah kolang kaling. Jurnal Photon. 2015;5(2):53-62.

4. Arisman. Buku ajar ilmu gizi. Jakarta: EGC; 2009.

5. Wijaya $\mathrm{CH}$, Mulyono N. Bahan tambahan pangan: pewarna. Bogor: IPB Press; 2009.

6. Cahyadi W. Analisis \& aspek kesehatan bahan tambahan pangan. Jakarta: Bumi Aksara; 2009.

7. Badan Pengawasan Obat dan Makanan RI. Pedoman pertolongan keracunan untuk puskesmas. Jakarta: BPOM RI; 2005.

8. Sugiyatmi S. Analisis faktor-faktor risiko pencemaran bahan toksik boraks dan pewarna pada makanan jajanan tradisional yang dijual di pasar-pasar Kota Semarang tahun 2006 (tesis). Semarang: Universitas Diponegoro; 2006.

9. Karyono AS. Hubungan pengetahuan dengan praktek produsen kerupuk tentang penggunaan pewarna pada kerupuk iris dan kerupuk terung di Kota Magelang (skripsi). Semarang: Universitas Diponegoro; 2003. 
10. Djarismawati, Sugiharti, Nainggolan $R$ Pengetahuan dan perilaku pedagang cabe merah giling dalam penggunaan rhodamine $B$ di pasar tradisional di DKI Jakarta. Jurnal Ekologi Kesehatan. 2004;3(1):7-12.
11. Notoatmodjo S. Pendidikan dan perilaku kesehatan. Jakarta: Rineka Cipta; 2003.

12. Kurniawaty E, Oksariani A. Hubungan dan sikap pedagang cabe merah giling terhadap perilaku penggunaan pewarna rhodamin B di lima pasar tradisional Bandar Lampung. JUKE. 2010;3(1):24-6 